\title{
Effects of Stem Rust (Puccinia graminis f.sp. tritici) on Yield, Physical and Chemical Quality of Durum Wheat Varieties in East Shoa Zone, Ethiopia
}

\author{
Ashenafi Gemechu Degete ${ }^{1}$, Alemayehu Chala ${ }^{2}$ \\ ${ }^{1}$ Ethiopian Institute of Agricultural Research (EIAR), Debre Zeit Agricultural Research Center, Debre Zeit, Ethiopia \\ ${ }^{2}$ Awassa College of Agriculture, University of Hawassa, Awassa, Ethiopia
}

Email address:

gemechuashenafi@gmail.com (A. G. Degete), alemayehuchala $a$ yahoo.com (A. Chala)

\section{To cite this article:}

Ashenafi Gemechu Degete, Alemayehu Chala. Effects of Stem Rust (Puccinia graminis f.sp. tritici) on Yield, Physical and Chemical Quality of Durum Wheat Varieties in East Shoa Zone, Ethiopia. American Journal of Agriculture and Forestry. Vol. 7, No. 2, 2019 , pp. $78-83$.

doi: 10.11648/j.ajaf.20190702.15

Received: January 2, 2019; Accepted: February 7, 2019; Published: May 17, 2019

\begin{abstract}
Stem rust or black rust caused by Puccinia graminis f.sp. tritici is one of the major biotic constraints of wheat production in Ethiopia. The disease may cause substantial quantitative and qualitative yield losses but much of the work in Ethiopia on this pathosystem focuses on quantitative yield loss and qualitative losses are often overlooked. As the result, the current research was designed with the objective of elucidating the effect of wheat stem rust on yield, physical and processing quality of durum wheat. For this purpose, a factorial field experiment involving three durum wheat varieties (Ude, Denbi and Hitosa) were selected and Tilt application was conducted at Debre Zeit Agricultural Research Centre for two cropping seasons (2016-2017). The experiment was laid out in randomized complete block design with three replications and untreated checks were included for comparison purpose. Results revealed significant variations in disease parameters and crop performance of treated plots, wheat varieties and their interactions. Stem rust severity was significantly reduced by the application of Tilt across all wheat varieties, and the highest decrease in disease level (8.9 and 15.2\%) was achieved by Tilt application in 2017 and 2016 cropping seasons, respectively. Correlation analysis revealed negative relationship between stem rust and durum wheat grain yield and quality parameters, which was highly significant in most cases. However, there was highly significantly positive correlation $\left(\mathrm{r}=0.31^{* *}\right.$ and $\left.\mathrm{r}=0.39^{* * *}\right)$ between stem rust and grain protein content during the year of 2016 and 2017 cropping seasons, respectively. The results confirmed the economic importance of stem rust to food industry for its effect on grain yield, physical and processing quality of durum wheat in Ethiopia.
\end{abstract}

Keywords: Disease Severity, Durum Wheat, Fungicide, Physical, Processing, Stem Rust

\section{Introduction}

Durum wheat (Triticum turgidum) is among the most important cereal crops in Ethiopia. It is widely cultivated in some parts of Ethiopia, including the Bale highlands. However, its production and quality is affected by abiotic and biotic factors. Among the biotic factors, stem rust (Puccinia graminis f.sp. tritici) is becoming a leading bottleneck of durum wheat production in the country, affecting both quantitative and qualitative yield of the crop.

Nowadays, durum wheat is considered as potential crop by the government for food industry as import substitution and one means of income diversification for the farmers. With the increasing number of processing industries, the demand for durum wheat grains for pasta processing is growing in the country. In 2012 Ethiopia imported 472,147t of durum wheat, at a cost of 174.6 million dollars [6]. The same author also reported that 27 cooperatives and five unions in the districts of Agarfa, Goro, Ginir, Gololcha, Sinana and Dello Mena are the main beneficiaries and simultaneously actors of the economic growth and development endeavor in producing durum wheat for different pasta and macaroni factories.

Nevertheless, due to various reasons, locally produced durum wheat grains are censured to be of poor quality and do not meet the minimum quality standard of pasta production. Hence, in spite of the large volume of local production, some 
processing industries prefer to import durum wheat grain for pasta production [2].

The acceptability of durum wheat varieties are greatly influenced by their quality characteristics as it is an important aspect of durum wheat. Grain protein content is considered as the main characteristic of durum wheat grain quality [7]. Differences in cooking quality among wheat varieties are mainly due to the differences in starch granule in the endosperm, attributed to the protein content and composition of the endosperm [12]. These characteristics tend to be cultivar-dependent [13].

In Ethiopia from time to time there is a problem of foliar diseases of bread and durum wheat that cause reduction in grain weight, grain size and yield. Particularly stem rust is the most important disease. Relationship between stripe rust (Puccinia striiformis) and grain quality of bread wheat has been studied in Ethiopia [15] and also the effect of Tilt on the development of wheat stem rust and yield of bread wheat varieties have been studied [17].

In spite of its importance, stem rust has been one of the most scantily studied disease in relation to its effect on durum wheat yield, physical quality traits of hectolitre weight, thousand kernel weight and seed size and processing quality traits including, grain protein, gluten and ash contents with and without the application of Tilt. Therefore, the present study aims to contribute towards integrated management of wheat stem rust for improved physical and processing quality of durum wheat in Ethiopia.

\section{Materials and Methods}

The experiment was carried out at Debre Zeit Agricultural Research Centre (DZARC) $\left(8^{\circ} 44^{\circ} \mathrm{N}, 39^{\circ} 02^{\prime} \mathrm{E}\right)$ during 2016 and 2017 cropping seasons. Debre Zeit is mid-highland (1900m.a.s.1.) characterized by moderate rainfall $(851 \mathrm{~mm}$ total annual rainfall); average minimum temperature of $8.9^{\circ} \mathrm{C}$ and mean maximum temperature of $28.3^{\circ} \mathrm{C}$. The soil is characterized as pellic vertisol. Three durum wheat varieties released from Debre Zeit Agricultural Research Centres were used. These varieties were selected based on their response to stem rust and other diseases like Fusarium spp, Septoria spp, leaf and stripe rusts and yield potential. Propiconazole (Tilt ${ }^{\circledR}$ 250 E. C.) was applied at a rate of $0.51 /$ ha was applied for treated plots and there were also untreated plots for comparison purpose. The application was made after the appearance of diseases symptoms on the hosts and when stem rust severity on the spreader rows reached $30 \%$.

Each experimental plot was $2.5 \mathrm{~m}$ long and $1.2 \mathrm{~m}$ wide, with six rows each spaced $20 \mathrm{~cm}$ apart, giving a plot area of $3 \mathrm{~m}^{2}$. The space between plots and blocks were $1 \mathrm{~m}$ and $1.5 \mathrm{~m}$, respectively. Wheat seed was hand drilled at a rate of $150 \mathrm{~kg} / \mathrm{ha}$ and covered lightly with soil.

Fertilizer rates were $41 \mathrm{~kg} /$ ha N (50kg urea) and $46 \mathrm{~kg} / \mathrm{ha}$ $\mathrm{P}_{2} \mathrm{O}_{5}$ (100kg DAP) and were applied during planting. Three to four times hand weeding were carried out during the crop growing season to make the plots weed free.

\subsection{Inoculation}

Stem rust epidemic was initiated by inoculating spreader rows with the mixture of virulent stem rust races of TTKSK, JRCQC, TRTTF and TKTTF at equal proportions $(0.6 \mathrm{mg}$ each). The spreader rows included Morocco, Digalu, Arendato and PBW343 and they were planted in a mixture of $25 \%$ each.

Spreader was planted along the border of experimental plots [19] seven days before the test varieties were planted. Each spreader row was inoculated with $0.6 \mathrm{mg}$ spore of each race mixtures following the method proposed by [23]. According to these authors about 1000 spores of cells are required to inoculate a single plant.

A total of three inoculations were carried out to ensure enough disease pressure and inoculums source to the experimental field. The first two inoculations were done through injection at stem elongation growth stage [24]. Injection of the spreader rows was done at $0.5 \mathrm{~m}$ intervals using $10 \mathrm{ml}$ syringe and a total of 104 plants were inoculated for each single row spreader.

\subsection{Disease Assessment}

From each plot about twenty plants were selected and disease scored for each selected plants. Disease scoring started a week before the first spraying and continued for four times at 10 days interval.

\subsection{Data Analysis}

Data on terminal stem rust severity, hectoliter weight, thousand kernel weight, grain protein content, grain gluten content, ash content, kernel size and yield were subjected to analysis of variance using GLM procedure of the System Analysis Software [11].

Least Significant Difference (LSD 0.05) was employed to compare treatment means. Data on stem rust yield and quality parameters were correlated using the Proc-Corr procedures of SAS [11].

\section{Results and Discussion}

\subsection{Terminal Stem Rust Severity}

Due to heterogeneity of data over cropping years, combined analysis of terminal severity, yield, chemical and physical qualities were not done.

During 2016 cropping season, terminal stem rust severity on untreated plots was $63.3 \%$ on both susceptible varieties (Denbi and Hitosa), 66.7\% on moderately susceptible variety of Ude (Table 1). Terminal stem rust severity on treated plots during the same year varied between 10.7 and $20 \%$ on susceptible varieties, $30 \%$ on moderately susceptible variety suggesting a significant reduction in stem rust disease level as the result of fungicide sprays.

During the year of 2017 cropping season, terminal stem rust severity on untreated plots ranged from 26.7 to $30 \%$ on susceptible varieties, $25 \%$ on moderately susceptible 
varieties (Table 1). On the other hand, terminal stem rust severity on treated plots during 2017 season ranged from 8.3 to $18.3 \%$ on susceptible varieties, $7.3 \%$ on moderately susceptible variety. [22] reported that application of Tilts effectively reduced disease severity

Overall terminal disease severity was lower in 2017 cropping season as compared to 2016 cropping season. This might be due to relatively dry and low rain fall conditions, which might be less favourable to disease development.

\subsection{Yield and Physical Quality Parameters}

The Tilt application created significantly different levels of terminal stem rust severity across the durum wheat varieties that enabled to assess the effects of stem rust disease on durum wheat grain yield and quality during both cropping seasons.

In general, the analysis of variance revealed significant ( $\mathrm{P}$ $<0.01$ ) differences among Tilt treated and untreated plots in hectolitre weight (HLW), thousand kernel weight (TKW), kernel size and yield during 2016 and 2017 cropping seasons at Debre Zeit.

The physical characteristics of durum wheat, such as test weight, thousand kernel weight and kernel size have been known to influence the milling performance of durum wheat and also pasta quality directly or indirectly [1]. So results of the current experiment will have implications on the management of stem rust for improved qualitative and quantitative yield of durum wheat.

\subsubsection{Grain Yield}

Estimating yield loss by a disease is a prerequisite to develop strategies for disease control particularity through breeding objectives for disease resistance [20].

During 2016 cropping season, yield on untreated plots varied from 4.7 to $5.7 \mathrm{t} \mathrm{ha}^{-1}$ on susceptible varieties (Denbi and Hitosa), whereas, it was $5.7 \mathrm{t} \mathrm{ha}^{-1}$ on moderately susceptible variety of Ude (Table 1). During the same cropping year, a maximum yield of $7.0 \mathrm{t} \mathrm{ha}^{-1}$ was obtained from treated plots of both susceptible varieties; whilst grain yields of 7.0 tha $^{-1}$ was obtained from fungicide treated of moderately susceptible variety. Similarly [21] reported that stem rust reduced yield irrespective of the type and level of resistance possessed by the varieties.

Results suggest the effect of fungicides may have in improving yield performance of susceptible wheat varieties. Yield on untreated plots during 2017 cropping season ranged from 5.3 to $6.3 \mathrm{t} \mathrm{ha}^{-1}$ on susceptible varieties, $5.3 \mathrm{t} \mathrm{ha}^{-1}$ on moderately susceptible variety. Whereas, yield on treated plots during the same cropping season varied from 7.0 to 8.0 $\mathrm{t} \mathrm{ha}^{-1}$ on susceptible varieties, $7.7 \mathrm{tha}^{-1}$ on moderately susceptible variety (Table 1). [18] also reported that the Tiltprotected plots remained almost free from stem rust.

\subsubsection{Hectoliter Weight}

During 2016 cropping season, hectolitre weight on untreated plots varied from 72.0 to $73.8 \mathrm{kghl}^{-1}$ on susceptible varieties (Denbi and Hitosa), $71.0 \mathrm{kghl}^{-1}$ on moderately susceptible variety Ude (Table 1). In the same season the hectolitre weight on treated plots ranged from 78.3 to 79.1 $\mathrm{kghl}^{-1}$ on susceptible varieties, $77.1 \mathrm{kghl}^{-1}$ on moderately susceptible variety.

Hectolitre weight on untreated plots during 2017 planting season varied from 72.5 to $73.6 \mathrm{kghl}^{-1}$ on susceptible varieties, $72.4 \mathrm{kghl}^{-1}$ on moderately susceptible variety. During this year hectolitre weight on treated plots varied from 79.5 to $79.9 \mathrm{kghl}^{-1}$ on susceptible varieties and $79.1 \mathrm{kghl}^{-}$ ${ }^{1}$ on moderately susceptible variety. [15] also reported that stripe rust has decreased hectolitre weight of grains harvested from unsprayed plots than frequently sprayed plots. [14] found a strong relationship between semolina yield and test weight for durum wheat for two consecutive crop years. The highest mean value of hectolitre weight $\left(79.2 \mathrm{kghl}^{-1}\right.$ and $76.7 \mathrm{kghl}^{-1}$ ) was obtained from the Tilt treated plots during 2016 and 2017 cropping seasons, respectively.

However, the hectolitre weight measured was below the acceptable range (72.8 to $84 \mathrm{~kg} \mathrm{~h}^{-1}$ ) according to the ICARDA guidelines.

\subsubsection{Thousand Kernel Weight}

During the year 2016 planting season thousand kernel weight (TKW) on untreated plots ranged from 36.4 to $38 \mathrm{~g}$ on susceptible varieties (Denbi and Hitosa), 44.8g on moderately susceptible variety (Ude) (Table 1). Thousand kernel weight on treated plots during the same season varied from 40.9 to $44.5 \mathrm{~g}$ on susceptible varieties and $51.7 \mathrm{~g}$ on moderately susceptible variety.

Thousand kernel weight on untreated plots during 2017 cropping season varied from 35.7 to $37.7 \mathrm{~g}$ on susceptible varieties, $40.7 \mathrm{~g}$ on moderately susceptible variety.

During this season thousand kernel weight on treated plots ranged from 46.3 to $44.8 \mathrm{~g}$ on susceptible varieties and $44.8 \mathrm{~g}$ on moderately susceptible variety.

[17] also reported significant increase in TKW as results of Tilt treatments. [4] also found that diseases such as stripe rust and root rots decrease the thousand kernel weight but also increase the protein levels in the grain.

\subsubsection{Kernel Size}

During 2016 cropping season, the same kernel size $(2.9 \mathrm{~mm})$ resulted on both susceptible varieties (Denbi and Hitosa) from untreated plots. On the other hand, kernel size varied from $3.0 \mathrm{~mm}$ on moderately susceptible variety (Ude) for untreated plots. During this year the kernel size on treated plots varied 3.0 to $3.3 \mathrm{~mm}$ on susceptible varieties, and also $3.4 \mathrm{~mm}$ on moderately resistant varieties (Table 1 ).

On the other hand, the kernel size on untreated plots during 2017 cropping season was 2.7 to $2.8 \mathrm{~mm}$ on susceptible varieties, $2.9 \mathrm{~mm}$ on moderately susceptible variety. During this cropping season kernel size on treated plots varied from 3.0 to $3.1 \mathrm{~mm}$ on susceptible varieties, $3.4 \mathrm{~mm}$ on moderately susceptible variety (Table 1 ). Infection of wheat stem and leaf sheaths by wheat stem rust affects the transport of assimilates to the developing kernel and results in shrivelled kernel which affects yield and quality of wheat $16,25]$. 
Table 1. The Tilt application and variety on yield and physical quality traits of durum wheat varieties during 2016 and 2017 cropping seasons at Debre Zeit.

\begin{tabular}{llllllll}
\hline \multirow{2}{*}{ Varieties } & Treatment & $\mathbf{2 0 1 6}$ & & & & \\
\cline { 2 - 7 } & & Trs & AUDPC & Yield (tha ${ }^{-1}$ ) & HLW (Kg/hl) & TKW (g) & Seed size (mm) \\
\hline \multirow{2}{*}{ Ude (MS) } & No spray & 66.7 & 991.7 & 5.7 & 71.0 & 44.7 & 3.0 \\
& sprayed & 30 & 500 & 7.0 & 77.1 & 51.7 & 3.4 \\
Denbi (S) & No spray & 63.3 & 866.7 & 4.7 & 72.0 & 36.4 & 2.9 \\
& sprayed & 20 & 366.7 & 7.0 & 79.0 & 44.5 & 3.3 \\
Hitosa (S) & No spray & 63.3 & 783.3 & 4.7 & 73 & 38 & 2.9 \\
CV\% & Sprayed & 16.7 & 291.7 & 7.0 & 78.3 & 40.9 & 3.0 \\
LSD (5\%) & & 18.4 & 24.7 & 16.4 & 1.06 & 4.39 & 0.7 \\
\hline
\end{tabular}

Table 1. Continued.

\begin{tabular}{llllllll}
\hline \multirow{2}{*}{ Varieties } & Treatment & $\mathbf{2 0 1 7}$ & & & & \\
\cline { 3 - 7 } & & Trs & AUDPC & Yield (t ha $\left.\mathbf{- 1}^{-1}\right)$ & HLW (Kg/hl) & TKW (g) & Seed Size (mm) \\
\hline \multirow{2}{*}{ Ude (MS) } & No spray & 25 & 286.7 & 5.3 & 72.4 & 40.7 & 2.9 \\
& sprayed & 7.3 & 80 & 7.7 & 79.1 & 52.3 & 3.2 \\
Denbi (S) & No spray & 26.7 & 228.3 & 6.3 & 72.5 & 35.7 & 2.7 \\
& sprayed & 18.3 & 135 & 8.0 & 79.9 & 46.3 & 3.0 \\
Hitosa (S) & No spray & 30 & 250 & 5.3 & 73.6 & 37.7 & 2.8 \\
CV\% & Sprayed & 8.3 & 86.67 & 7.0 & 79.5 & 44.8 & 3.1 \\
LSD (5\%) & & 48.12 & 49.70 & 14.08 & 3.39 & 13.35 & 0.2 \\
\hline
\end{tabular}

Trs= Terminal rust severity; HLW=Hectolitre weight; TKW= Thousand kernel weight; AUDPC $=$ Area under disease progress curve

\subsection{Chemical Quality Parameters}

\subsubsection{Total Grain Protein Content}

During 2016 cropping season, total grain protein content on untreated plots ranged between 15 to $15.7 \%$ on susceptible varieties (Denbi and Hitosa), $14.5 \%$ on moderately susceptible variety (Ude) (Table 2). [9] reported that stripe rust increased grain protein content due to the shrivelling of the kernels. On the other hand, on treated plots it varied from 12.9 and $13.43 \%$ on susceptible varieties, $13.5 \%$ on moderately susceptible variety.

During the off-season, the grain protein content on untreated plots varied from 14.67 to $14.9 \%$ on susceptible varieties and $14.5 \%$ on moderately susceptible variety. [10] also reported the increment of protein content due to the effect of leaf rust. During the same year grain protein content on treated plots ranged from 12.93 to $13.53 \%$ on susceptible varieties, $12.83 \%$ on moderately susceptible variety (Table 2).

\subsubsection{Ash Content}

Ash content on untreated plots during 2016 cropping season ranged from 1.44 to $1.8 \%$ on susceptible varieties, $1.77 \%$ on moderately susceptible variety. During this cropping season, ash content on treated plots varied from 1.89 to $1.94 \%$ on susceptible varieties and $1.92 \%$ on moderately susceptible variety (Ude).

On the other hand, during 2017 cropping season the ash content on untreated plots ranged between 1.38 to $1.55 \%$ on susceptible varieties and $1.62 \%$ on moderately susceptible variety. During 2017 planting season ash content on treated plots varied from 1.84 to $1.88 \%$ on susceptible varieties and $1.84 \%$ on moderately susceptible variety (Table 2 ). Durum wheat varieties usually contain 1.6 to $2.3 \%$ ash $\mathrm{db}$ [3].

\subsubsection{Grain Gluten Content}

The grain gluten content during 2016 cropping season for untreated plots varied from 24.7 and $28.9 \%$ on Denbi and Hitosa and $24.5 \%$ on Ude variety. On the other hand, grain gluten content for treated plots during 2016 cropping season ranged between 32.93 and $35.67 \%$ on susceptible varieties, $32.53 \%$ on moderately susceptible variety.

During 2017 planting season, the grain gluten content on untreated plots ranged from 23.5 and $24.8 \%$ on susceptible varieties and also $25.7 \%$ on moderately susceptible variety. During the same year grain gluten content on treated plots ranged from 29.7 and $31.7 \%$ on susceptible varieties, $29.8 \%$ on moderately susceptible variety (Table 2). [5] reported a highly significant positive correlation between gluten content and total protein content in hard bread wheat cultivars ( $\mathrm{r}=$ 0.98).

Table 2. The effect of variety and Tilt application on chemical quality traits of durum wheat varieties during 2017 and 2016 planting seasons at Debre Zeit.

\begin{tabular}{|c|c|c|c|c|c|c|c|c|c|c|c|}
\hline \multirow{3}{*}{ Varieties } & \multirow{3}{*}{ Treatment } & \multicolumn{5}{|l|}{2017} & \multicolumn{5}{|l|}{2016} \\
\hline & & \multicolumn{2}{|l|}{ Terminal } & \multirow{2}{*}{ Protein (\%) } & \multirow{2}{*}{ Ash (\%) } & \multirow{2}{*}{ Gluten (\%) } & \multicolumn{2}{|l|}{ Terminal } & \multirow{2}{*}{ Protein (\%) } & \multirow{2}{*}{ Ash (\%) } & \multirow{2}{*}{ Gluten (\%) } \\
\hline & & Severity & AUDPC & & & & Severity & AUDPC & & & \\
\hline \multirow{2}{*}{ Ude (MS) } & No spray & 25 & 286.7 & 14.53 & 1.62 & 25.67 & 66.7 & 991.7 & 14.4 & 1.77 & 24.5 \\
\hline & Sprayed & 7.3 & 80 & 12.83 & 1.84 & 29.77 & 30 & 500 & 13.5 & 1.92 & 32.53 \\
\hline \multirow{2}{*}{ Denbi (S) } & No spray & 26.7 & 228.33 & 14.9 & 1.38 & 23.47 & 63.3 & 866.7 & 15.7 & 1.44 & 24.73 \\
\hline & Sprayed & 10.3 & 135 & 13.5 & 1.88 & 29.67 & 20 & 366.7 & 12.9 & 1.9 & 30.53 \\
\hline
\end{tabular}




\begin{tabular}{|c|c|c|c|c|c|c|c|c|c|c|c|}
\hline \multirow{3}{*}{ Varieties } & \multirow{3}{*}{ Treatment } & \multicolumn{5}{|l|}{2017} & \multicolumn{5}{|l|}{2016} \\
\hline & & \multicolumn{2}{|l|}{ Terminal } & \multirow{2}{*}{ Protein (\%) } & \multirow{2}{*}{ Ash (\%) } & \multirow{2}{*}{ Gluten (\%) } & \multicolumn{2}{|l|}{ Terminal } & \multirow{2}{*}{ Protein (\%) } & \multirow{2}{*}{ Ash (\%) } & \multirow{2}{*}{ Gluten (\%) } \\
\hline & & Severity & AUDPC & & & & Severity & AUDPC & & & \\
\hline & No spray & 30 & 250 & 14.5 & 1.55 & 25.67 & 63.3 & 783.3 & 15 & 1.55 & 28.9 \\
\hline Hitosa (S) & Sprayed & 8.3 & 86.67 & 12.93 & 1.84 & 31.7 & 16.7 & 291.7 & 13.4 & 1.86 & 33.43 \\
\hline CV (\%) & & 48.12 & 49.70 & 3.9 & 12.25 & 4.7 & 18.4 & 24.7 & 7.5 & 10.5 & 5.9 \\
\hline $\operatorname{LSD}(0.05)$ & & 12.81 & 86.07 & 0.31 & 0.31 & 0.79 & 10.46 & 205.4 & 1.7 & 0.3 & 2.9 \\
\hline
\end{tabular}

LSD $(5 \%)=$ Least Significant Different; CV= Coefficient of Variation; MS= Moderately Susceptible; $\mathrm{S}=$ Susceptible

\subsection{Correlation Between Final Rust Severity, Yield and Quality Parameters}

Correlation analysis among final stem rust severity, yield and quality parameters revealed the negative impact stem rust may have on durum wheat quantitative and qualitative yield except for grain protein content, which was positively influenced by stem rust disease during both cropping seasons (Tables 3 and 4).
Grain yield was negatively correlated with all of the three disease parameters (terminal severity, average coefficient of infection and AUDPC) but the correlation was significant only during 2016 cropping season. [9] reported that yield was correlated strongly with area under disease progress curve. This might be due to unfavourable environmental conditions for the development of stem rust during the off-season.

Table 3. Correlation coefficient between final stem rust severity, yield and quality traits of durum wheat during 2016 cropping season at Debre Zeit.

\begin{tabular}{|c|c|c|c|c|c|c|c|}
\hline & Frs & Yield & HLW & TKW & G p & Ash & GC S Size \\
\hline \multicolumn{8}{|l|}{ Frs } \\
\hline Yield & $-0.41 * * *$ & & & & & & \\
\hline HLW & $-0.49 * * *$ & $0.87 * * *$ & & & & & \\
\hline TKW & -0.72 & 0.18 & 0.20 & & & & \\
\hline G p & $0.31 * *$ & $-0.35 * *$ & $-0.36 * * *$ & $0.04-$ & & & \\
\hline Ash & -0.19 & $0.28 *$ & $0.39 * * *$ & $0.24 *$ & -0.19 & & \\
\hline $\mathrm{G} \mathrm{C}$ & $-0.37 * * *$ & $0.62 * * *$ & $0.63 * * *$ & $0.23 *$ & $-0.23^{*}$ & $0.27 *$ & \\
\hline
\end{tabular}

Frs= Final rust severity; HLW=hectolitre weight; TKW= thousand kernel weight; G. $\mathrm{P}=$ protein content; G. $\mathrm{C}=$ gluten content; S. Size $=$ seed size $* * *, * * *$ correlation coefficient

Table 4. Correlation coefficient between final stem rust severity, yield and quality traits of durum wheat during 2017 cropping season.

\begin{tabular}{|c|c|c|c|c|c|c|c|c|}
\hline & Frs & Yield & HLW & TKW & $G \quad p$ & Ash & G_C & S. S \\
\hline \multicolumn{9}{|l|}{ Frs } \\
\hline Yield & $-0.26^{*}$ & & & & & & & \\
\hline HLW & $-0.37 * *$ & $0.33 * *$ & & & & & & \\
\hline TKW & $-0.72 * * *$ & 0.11 & 0.18 & & & & & \\
\hline G_p & $0.39 * * *$ & $-0.25^{*}$ & -0.16 & $-0.32 * *$ & & & & \\
\hline Ash & 0.03 & -0.21 & -0.03 & 0.05 & -0.01 & & & \\
\hline G_C & $-0.39 * * *$ & -0.01 & 0.22 & $0.23 *$ & -0.16 & -0.10 & & \\
\hline S_Size & $-0.81 * * *$ & 0.15 & $0.25 *$ & $0.89 * * *$ & $-0.33 * *$ & 0.10 & 0.21 & \\
\hline
\end{tabular}

$\mathrm{Frs}=$ Final rust severity; HLW=hectoliter weight; TKW= thousand kernel weight; $\mathrm{G}$. $\mathrm{C}=$ protein content; $\mathrm{G}$. $\mathrm{C}=\mathrm{gluten}$ content; $\mathrm{S}$. $\mathrm{S}=\mathrm{seed}$ size $* * *, * * *$ Correlation coefficient

\section{Conclusion}

Stem rust disease resulted in significant reduction in hectolitre weight (HLW), thousand kernel weight (TKW), kernel size and yield during both cropping years when left untreated. The disease also significantly reduced processing quality parameters when unchecked. However, Tilt application significantly reduced terminal stem rust severity and there by significantly improved grain yield and quality of durum wheat.

The current study also revealed highly negative correlation of final stem rust severity with physical and chemical quality traits except for grain protein contents, which showed a highly significantly $\left(\mathrm{r}=0.31^{* *}\right.$ and $\mathrm{r}=0.39 * * *$ ) positive correlation with final stem rust severity during the years of 2016 and 2017, respectively. Overall results of the correlation analyses suggest strong negative relationship between stem rust and durum wheat kernel weight and grain quality that may have a negative effect on marketability of the grain.

Current results not only demonstrated the negative impact of stem rust on grain yield and quality parameters of durum wheat, but also the role of fungicide application which reduce stem rust severity and hence it was possible to improve grain yield, physical and chemical quality of the produce.

The results confirmed the economic importance of stem rust to food industry for its effect on grain yield, physical and processing quality of durum wheat in Ethiopia. 


\section{References}

[1] Aalami, M., Rao, U. P. and Leelavathi, K. 2007. Physicochemical and biochemical characteristics of Indian durum wheat varieties: Relationship to semolina milling and spaghetti making quality. Food Chemists. 102:993-1005.

[2] Ayele Badebo, Solomon Gelalcha, Ammar, K., Nachit, M. M., \& Abdalla, O. 2009. Overview of durum wheat research in Ethiopia: Challenges and prospects. Paper presented at the Proceedings of Basra, and L. S. Randhawa ( eds.), Quality Improvement in Field Crops, Food Products Press, Binghamton, New York. Food Chemistry. 124:816-821.

[3] Canadian Wheat Commission (CWC), 2005. Description of durum wheat semolina quality factors. http://www. californiawheat. org Accessed 12 July 2016. 115 pp.

[4] Cromey, M. G., Harvey I. C., Braithwaite, M. Farrell, J. A. and Ganev. K. S. 1992. Effects of diseases and pests on yield and quality of wheat. New Zealand Institute for Crop and Food Research Limited Private Bag 4704, Christchurch Wheat Symposium.

[5] Hussain, A., Lukow, O. M. and McKenzie, R. I. H. 1998. Rheological properties of gluten derived from wheat cultivars with identical HMW glutenin subunit composition. Journal of the Science of Food and Agriculture. 78:551-558.

[6] Yetneberk Tadele. 2013. Oromia Farmers sell 2,000tn of Pasta Wheat to Local FactoriesFortune Staff Writer Published on March 3, 2013 (13) 67pp.

[7] Ottman, M. J., Doerge T. A. and Martin E. C. 2000. Durum Grain Quality as Affected by Nitrogen Fertilization near Anthesis and Irrigation during Grain Filling. Agronomy Journal. 92:1035-1041.

[8] Obrien, L., Brown, J. S., Panozzo, J. F. and Archer, M. J. 1990. The effect of stripe rust on the quality of Australian wheat varieties. Australian Journal of Agricultural Research. 41:827- 839 .

[9] Ochoa J., Parlevliet J. E., 2007. Effect of partial resistance to barley leaf rust, Puccinia hordei on the yield of three barley cultivars. Euphytica 153:309-312.

[10] Peturson, B. Margaret, N. and Whiteside, A. G. O. 2011. The effects of leaf rust on yield and quality of wheat. Canadian Journal of Research. 23:105-114.

[11] Statistical Analysis Software (SAS). 2004. SAS Institute Inc. Cary, North Carolina. First printing, January 2004. SAS Publishing provides. 513pp.

[12] Feillet, P. 1988. Protein and enzyme composition of durum wheat. In Fabriani, G. and C. Lintas (eds.) Durum Chemistry and Technology. AACC, State Paul, Minnesota. Pp. 93-119.

[13] Dexter, J. E. and Matsuo, R. R. 1977. Influence of protein content on some winter durum wheat quality parameters. Canadian Journal of Plant Science. 57:717-727.
[14] Dexter, J. E., Matsuo, R. R. and Martin, D. G. 1987. The effect of test weight on durum wheat quality. Cereal Foods of World. 32:772-777.

[15] Dereje Hailu and Cheneda Fininsa. 2007. Relationship between stripe rust (Puccinia striiformis) and grain quality of bread wheat (Triticum aestivum) in the highlands of Bale, Southeastern Ethiopia. International Journal of Food, Agriculture and Environment. 5:24-30.

[16] Everts, K. L., Leath, S., and Finney, P. L. 2001. Impact of powdery mildew and leaf rust on milling and baking quality of soft red winter wheat. Plant Disease. 85:423-429.

[17] Kebede Tadesse, Ayalew Amare. and Ayele Badebo. 2010. Effect of Tilt on the development of wheat stem rust and yield of wheat varieties in highlands of Ethiopia. African Crop Science Journal. 18:23 - 33.

[18] Mamdouh A. A, Walid, M. El-Orabey, M. N. 2013. Effect of stem rust infection on grain yield and yield components of some wheat cultivars in Egypt Shahin ESci Journal of Plant Pathology. 02 (03):171-178.

[19] Jin, Y., Singh, R. P., Ward, R. W., Wanyera, R., Kinyua, M., Njau, P., Fetch, T., Pretorius, Z. A., and Yahyaoui, A. 2007. Characterization of Seedling Infection Types and plant Infection Responses of Monogenic Sr Gene lines to Race TTKS of Puccinia graminis f.sp. tritici. Plant Disease. 91:1096-1099.

[20] Simmonds N. W. 1988. Synthesis the strategy of rust resistance breeding N. W. Simmonds and S. Rajaram (eds), Breeding Strategies for Resistance to the Rusts of wheat. CIMMYT, Mexico. Pp. $119-136$.

[21] Singh, R. P., Hodson, D. P., Huerta-Espino, J., Jin, Y. Njau, P., Wanyera, R., Herrera-Foessel, S. A., and Ward, R. W. 2008. Will Stem Rust Destroy the World's Wheat Crop? In "Advances in Agronomy Volume 98. (Sparks D. L. Eds). Elsevier Inc, USA. Pp. 271-309.

[22] Stephen N. Wegul; Breathnach, Julie A.; and Baenziger, P. Stephen. 2009. Effect of Growth Stage on the Relationship Between Tan Spot and Spot Blotch Severity and Yield in Winter Wheat. Papers in Plant Pathology, 159. Crop Protection. 28:696-702.

[23] Stubbs, R. W., Prescott, J. M., Saari E. E. and Dubin H. J. 1986. Cereal Disease Methodology Manual. Centro Internacional de Mejoramiento de Maiz y Trigo (CIMMYT), Mexico. 46pp.

[24] Zadkos, J. C., Chang, T. T. and Konzak, C. F. 1974. A decimal code for the growth stages of cereals. Weed Research. 14:415421.

[25] Singh R. S 1998. Plant Disease. Seventh edition. Oxford and IBH Publishing Company of private Limited, New York. Oxford and IBH Publishing Company Private Limited, New Delhi. 686pp. 